Article

\title{
Spatio-Temporal Analysis and Water Quality Indices (WQI): Case of the Ébrié Lagoon, Abidjan, Côte d'Ivoire
}

\author{
Coulibaly Naga ${ }^{1, *}$, Coulibaly Talnan Jean Honoré ${ }^{1}$, Ochou Abé Delfin ${ }^{2,3}$, \\ Yapo Ossey Bernard ${ }^{3,4}$, Zabi Soko Guillaume ${ }^{3}$, Aclohou Henoc Sosthène ${ }^{1}$, \\ Ziyanda Mpakama ${ }^{5}$ and Savané Issiaka ${ }^{1}$ \\ 1 Laboratoire de Géosciences et Environnement, UFR des Sciences et gestion de l'Environnement, \\ Université NANGUI ABROGOUA, Abidjan, Cote d'Ivoire; ctalnan@yahoo.fr (C.T.J.H.); \\ sothenehenoc@gmail.com (A.H.S.); savanei@hotmail.com (S.I.) \\ 2 Laboratoire de Physique de l'Atmosphère et de Mécanique de Fluides, UFR Sciences des Structures, \\ de la Matière et de Technologie, Université Félix Houphouët Boigny de Cocody, Abidjan, Cote d'Ivoire; \\ ochou.delfin@gmail.com \\ 3 Ministère de la Salubrité, de l'Environnement et du Développement Durable, Abidjan, Cote d'Ivoire; \\ yapossey@yahoo.fr (Y.O.B.); gzabi01@yahoo.fr (Z.S.G.) \\ 4 Laboratoire de Sciences de l'Environnement, UFR des Sciences et gestion de l'Environnement, \\ Université NANGUI ABROGOUA, Abidjan, Cote d'Ivoire \\ 5 Programme Manager Africa Regional Centre IStockholm International Water Institute (SIWI), Pretoria 0181, \\ South Africa; ziyanda.mpakama@siwi.org \\ * Correspondence: coulibalynaga@yahoo.fr; Tel: +225-05-83-75-99
}

Received: 31 December 2017; Accepted: 23 June 2018; Published: 28 June 2018

\begin{abstract}
For decades, the Ébrié Lagoon in Côte d'Ivoire has been the receptacle of wastewater effluent and household waste transported by runoff water. This work assesses the spatio-temporal variability of the Ébrié lagoon water quality at the city of Abidjan. The methodological approach used in this study is summarized in three stages: the choice and standardization of the parameters for assessing water quality for uses such as aquaculture, irrigation, livestock watering, and sports and recreation; the weighting of these parameters using the Hierarchical Analysis Process (AHP) of Saaty; and finally, the aggregation of the weighted parameters or factors. Physicochemical and microbiological analysis data on the waters of the Ébrié lagoon for June and December of 2014 and 2015 were provided by the Ivorian Center for Anti-Pollution (Centre Ivoirien Anti-Pollution, CIAPOL), and the concentrations of trace elements in sediments ( $\mathrm{As}, \mathrm{Cd}, \mathrm{Cr}, \mathrm{Pb}, \mathrm{Zn}$ ) were used. The aggregation of standardized and weighted parameters allowed the calculation of the Water Quality Indices (WQI) by usage for each bays of the lagoon. The results show that in both 2014 and 2015, the waters of the Ébrié lagoon were generally of poor quality for the different uses examined in this study (aquaculture, irrigation, livestock watering, and sport and recreation) with an accentuation in 2015. However, some bays of the lagoon have waters of dubious to satisfactory quality. This study contributes an improved evaluation of the Ébrié lagoon waters.
\end{abstract}

Keywords: Water Quality Indices; spatio-temporal analysis; Ébrié lagoon; surface water; Abidjan

\section{Introduction}

The coast of Côte d'Ivoire has a remarkable lagoon system. Although originally exceptional, the natural environments associated with this lagoon complex are now severely degraded, due to the intense human pressure exercised on this fragile space over decades. Since the 1970s and because of the 
development of the city of Abidjan [1], there has been increasing concern about this damage. Indeed, Côte d'Ivoire's industrial development has been heavily concentrated in the metropolitan area of Abidjan. In 2010, the National Institute of Statistics (Institut national de la statistique, INS) determined that $92.8 \%$ of the 2822 industrial establishments (agro-food, energy, chemical, textile, soap factory, an oil refinery, and many informal industries) in the country are located in the only economic capital of the country (Abidjan), and $60 \%$ of these establishments are installed around the Ébrié lagoon. The Ébrié lagoon has several bays in which untreated or insufficiently treated wastewater effluents (domestic, industrial wastewater, and so forth) or solid waste have been discharged for decades [2]. The biodegradable waste causes an intense eutrophication phenomena, especially in the low renewal areas such as bays [3]. To determine the quality of Ébrié lagoon water, many studies have been conducted since the 1980s [4-19]. Namely, Koné and Aka [18] showed that all the industries of the Abidjan agglomeration dumped their wastewater in the lagoon, with a total volume estimated at $12,000 \mathrm{~m}^{3}$ per day. These inputs are likely to contain metallic trace elements (ETM) such as lead $(\mathrm{Pb})$, chromium (Cr), zinc ( $\mathrm{Zn}$ ), arsenic (As), and cadmium (Cd) [16]. Kouamé et al. [19] observed a very large bioaccumulation of $\mathrm{Cr}$ and $\mathrm{Pb}$ in crab organisms (used as indicators of metal pollution) collected in the Ébrié lagoon.

These studies were focused on the assessment of biological and microbiological quality, pollution by oil, metal sediment contamination, and solid waste. Additionally, the Ivorian Center of Anti-Pollution (Centre Ivoirien d'Anti-Pollution, CIAPOL) systematically and periodically analyzes the natural waters from its National Observation Network (Réseau National d'Observation, RNO) as part of its mission. Thus, the water quality of the Ébrié lagoon is periodically analyzed in situ and in a laboratory, as part of the monitoring of this water body. Based on this important existing knowledge base on the Ébrié Lagoon, it is now necessary to introduce a Water Quality Indices (WQI) approach, which summarizes large quantities of data on water quality in to simple terms of water quality (Excellent, Good, Bad, and so forth), in order to supply synthetic and comprehensive information to the decision makers and the general public. WQIs minimize the volume of data and simplify the expression of water quality status based on a number of physicochemical and bacteriological parameters [20]. The first attempts to classify water by degree of purity date back to the mid-twentieth century [21]. Horton's pioneering efforts have been followed by number of researchers; various WQIs have been formulated and used by water supply and water pollution control agencies around the world [22-33].

The Ébrié Lagoon has always been the particularity of Abidjan. Thus, the potential of this underutilized water body is a major challenge for the development of the city if it wants to recover its nickname "Abidjan, the pearl of lagoons". To that end, it is necessary to develop indicators for decision-makers on the quality of these waters that are simplified and easily understood to support valuation of the lagoon water body. Thus, the main objective of this study is to perform a spatio-temporal assessment of the Ébrié lagoon water quality for uses such as aquaculture, irrigation, livestock watering, and sport and recreation using a multicriteria analysis method.

\section{Materials and Methods}

\subsection{Study Area}

The Ébrié lagoon is part of the Ivorian lagoon complex that was formed by tectonic depressions, causing a lagoon fault [34]. The Ébrié lagoon area is $523 \mathrm{~km}^{2}$ [1]. The volume of this lagoon is about 2.5 billion of $\mathrm{m}^{3}$, the average depth is $4.8 \mathrm{~m}$, and some pits near Abidjan exceed $20 \mathrm{~m}$ in depth. The lagoon waters are separated from the Gulf of Guinea (Atlantic Ocean) by a set of recent dune cordons formed in the Holocene period less than 10,000 years ago (Figure 1).

The climate of the region is of an equatorial type of transition characterized by four seasons with a heavy rainfall in the month of June $(367 \mathrm{~mm})$. The average annual rainfall in the district of Abidjan is between 1600 and $2400 \mathrm{~mm}$. The Ébrié lagoon is fed mainly by continental fresh waters from the Comoé, Agnéby, and Mé Rivers and has been open to marine waters since 1950 via the Vridi channel, 
while its natural outlet, the Comoé pass at Grand-Bassam, is now closed. The Comoé River alone is responsible for $70 \%$ of the freshwater inflow to the lagoon during the flood periods, i.e., $1814 \mathrm{~m}^{3} / \mathrm{s}$; for the Agnéby and Mé Rivers, it is 172 and $206 \mathrm{~m}^{3} / \mathrm{s}$ [1]. The inputs of this river are charged with fertilizer and pesticide residues and, periodically, with aquatic plants (freshwater hyacinth).

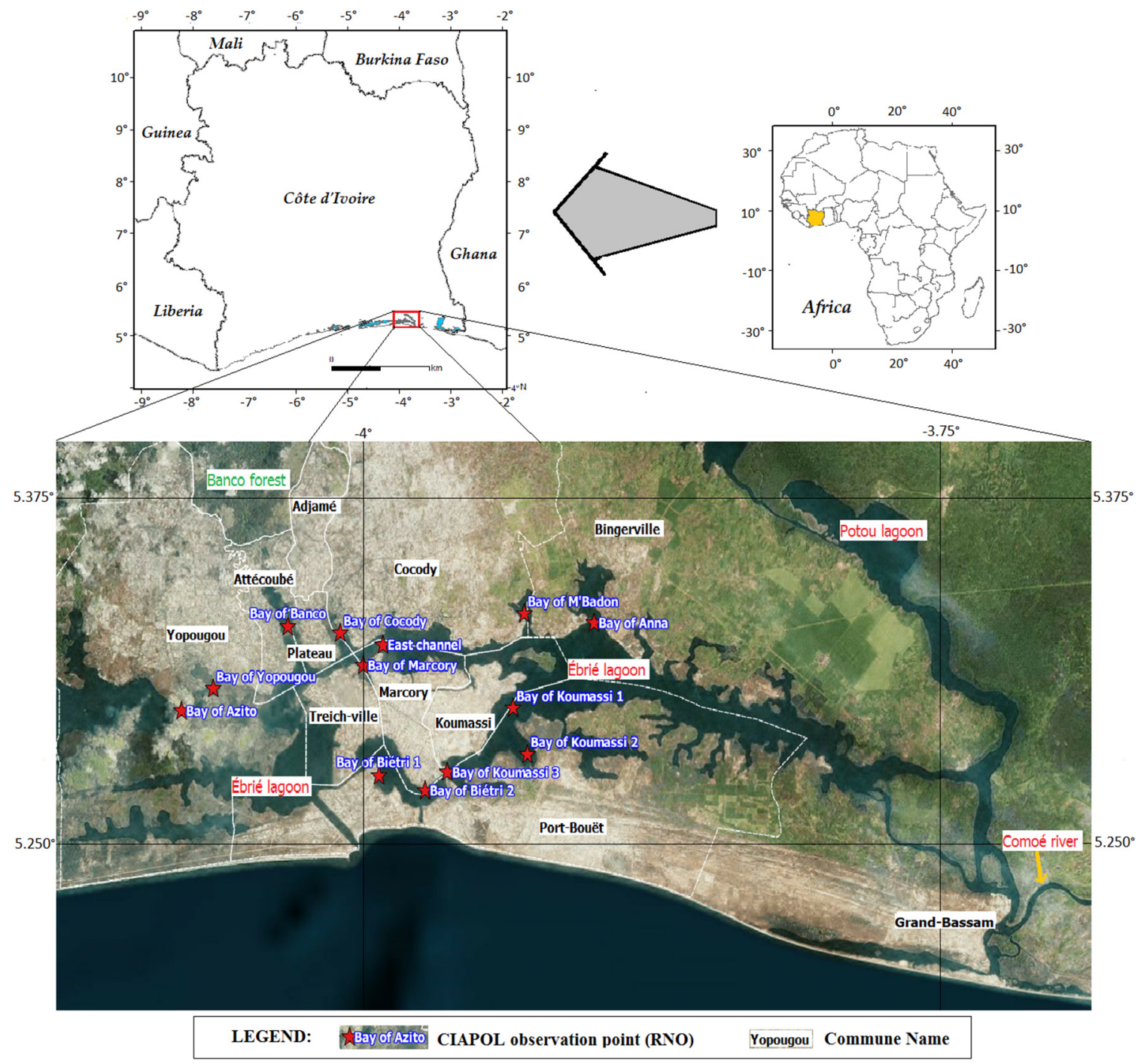

Figure 1. Presentation of Ébrié lagoon and the study area.

The Ébrié lagoon has a complex morphology consisting of multiple bays (Figure 1). The lagoon currentology confirms this complexity associated with the configuration of the water body. Ebb and flow tide currents act differently depending on the site. At the bays of Cocody, Banco, Biétry, Koumassi, and Marcory, the flow currents are more important than the ebb currents. Also, the configuration of their bays' axes perpendicular to the main channel axis of the lagoon involves bad exchanges with the main channel. According to Pottier et al. [1], the pollutants transported to these bays by the sewers, emissaries, and industrial waste disposal systems can't be easily evacuated (Figure 2).

The central part of the Ébrié lagoon, where the metropolitan area of Abidjan is located, is a chief concern of this study (Figure 1). The city of Abidjan, the economical capital of Côte d'Ivoire, has a population of 4.707 million inhabitants as of 2014, living in ten communes (Abobo, Adjamé, Attécoubé, Cocody, Koumassi, Marcory, Plateau, Port-Bouët, Treich-ville and Yopougon). Most of the country's industries are concentrated in Abidjan. The pollution of the lagoon is caused by excessive inputs 
of untreated domestic and industrial effluents (soap factories, oil mills, breweries, dairies, refineries, and so forth) and all kinds of solid waste. Since 1975, various works have shown the worrying level of bacterial contamination of the waters of the Ébrié lagoon [1].

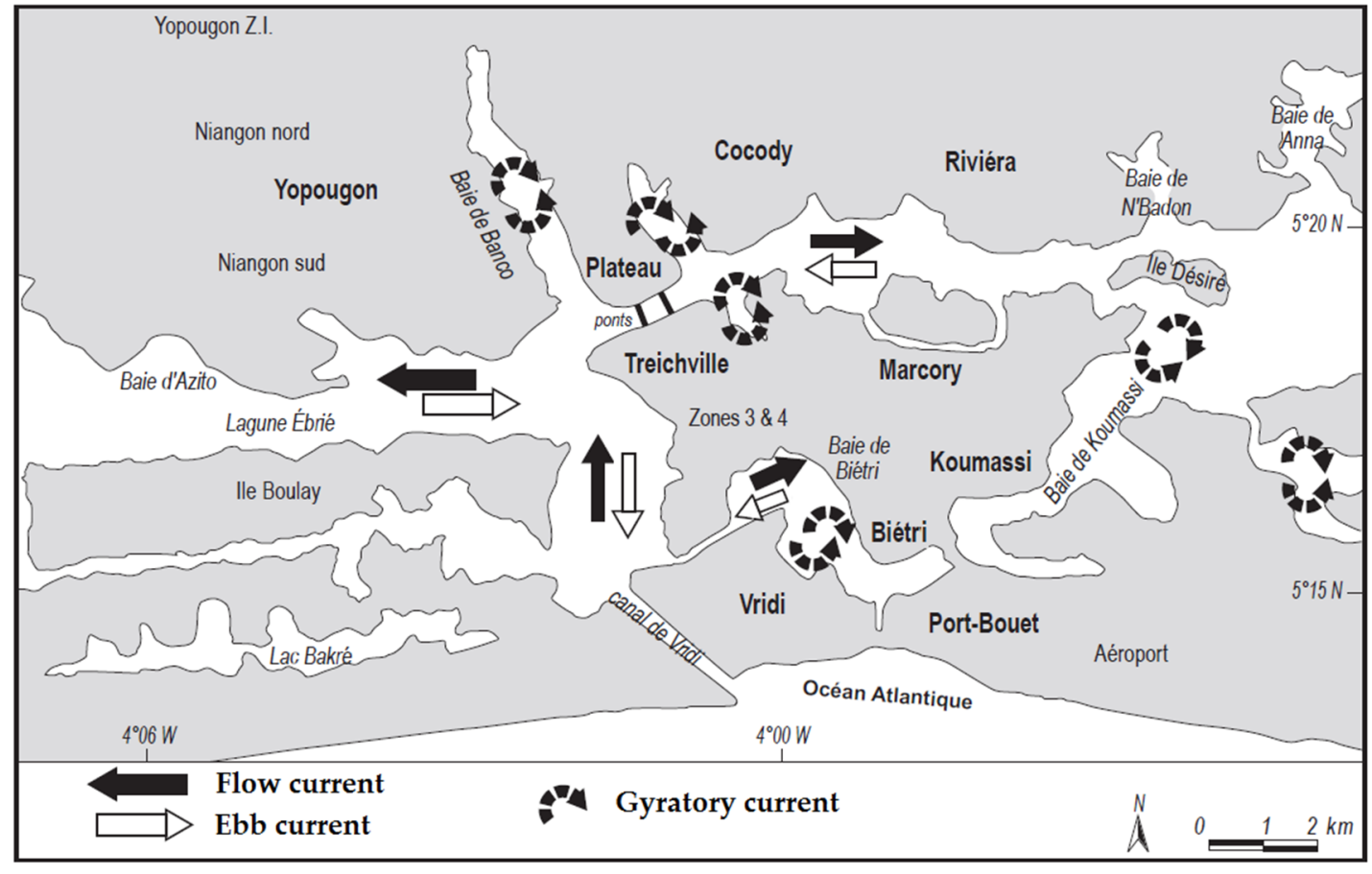

Figure 2. Simplified model of circulation in Ébrié lagoon of Abidjan (Source: Affian [35]).

\subsection{Data}

The data used in this study are the water and sediment quality of the Ébrié Lagoon and the map of the district of Abidjan. Data on the physico-chemical (Total suspended solids (TSS), SECCHI Transparency, oxygen, $\mathrm{BOD}_{5}, \mathrm{NO}_{2}(-)$, Nitrates, Sodium, Calcium, Sulfate) and biological (Total Coliform, Enterococci, Thermo tolerant Coliforms, Chlorophyll) quality of Ébrié lagoon water have been provided by the CIAPOL. These data are the results of in situ and laboratory analyses of samples taken on the surface of the lagoon waterbody during the months of June and December in 2014 and 2015. In this study, thirteen stations of the RNO of CIAPOL located at the Ébrié lagoon were considered. Also, this study includes an analysis of the trace metal elements (Arsenic, Cadmium, Total Chromium, Lead, Zinc) present in the sediments of the Ébrié lagoon bays extracted from Kouamé et al. [16]. The map of Abidjan at 1/25,000 from the "Centre d'Information Géographique et du Numérique" (CIGN) of the "Bureau National d'Etude Technique et de Développement" (BNETD) was used to extract the limits of the lagoon and the communes of Abidjan. All of the data were analyzed using the free open source software, Quantum GIS (QGIS), as well as the maps composition. QGIS is a GIS software which supports a number of data formats: vector (Shapefile, ArcInfo, Mapinfo, GRASS GIS, etc.), raster (GRASS GIS, GeoTIFF, TIFF, JPG, etc.), and spatial databases.

\subsection{Methods}

\subsubsection{Parameters of Different WQIs by Use and Their Classification}

Various parameters were selected for each type of use (see Table 1): Irrigation, livestock watering, aquaculture, and sports and recreation. These parameters are used in the SEQ-eau (Système d'Evaluation de la Qualité de l'eau) [36]. SEQ-eau is a tool used to evaluate and characterize the physical-chemical properties and microbiology of surface water or groundwater. 
Table 1. Parameters used for different uses.

\begin{tabular}{|c|c|}
\hline Usages & Parameters \\
\hline Sports and recreation & $\begin{array}{l}\text { Total suspended solids (TSS), Total Coliform (C.Total), Enterococci, } \\
\text { Thermotolerant Coliforms (C.Thermo), SECCHI Transparency (Secchi) }\end{array}$ \\
\hline Irrigation & $\begin{array}{l}\text { Total Coliform (C.Total), Thermotolerant Coliforms (C.Thermo), Lead (Pb), } \\
\text { Copper (Cu), Nickel (Ni), Total Chrome (Cr), Arsenic (As), Cadmium (Cd), } \\
\text { Zinc (Zn), Chlorides (Cl), Selenium (Se) }\end{array}$ \\
\hline Livestock watering & $\begin{array}{l}\mathrm{NO}_{2}(-) \text {, Nitrates }(\mathrm{N}) \text {, Sodium }(\mathrm{Na}) \text {, Calcium }(\mathrm{Ca}) \text {, Sulfate }\left(\mathrm{SO}_{4}(2-)\right) \text {, } \\
\text { Free cyanide, Zinc }(\mathrm{Zn}) \text {, Copper }(\mathrm{Cu}) \text {, Selenium, Arsenic (As), } \\
\text { Mercury }(\mathrm{Hg}) \text {, Lead }(\mathrm{Pb}) \text {, Nickel, Cadmium }(\mathrm{Cd}) \text {, Total Chrome }(\mathrm{Cr})\end{array}$ \\
\hline Aquaculture & $\begin{array}{c}\text { Chlorophyll a + pheopigments (Chlorophyll), } \mathrm{NO}_{2}{ }^{-}, \text {Free Cyanides }\left(\mathrm{CN}^{-}\right) \text {, } \\
\text { Mercury }(\mathrm{Hg}), \mathrm{NH}_{4}(+) \text {, Phosphor }(\mathrm{P}), \text { Oxygen }(\mathrm{O}), \text { Calcium }(\mathrm{Ca}), \mathrm{Copper} \\
(\mathrm{Cu}) \text {, Zinc (Zn), Nitrates (N), TSS, pH, BOD }, \text { Mercury }(\mathrm{Hg}) \text {, Lead (Pb), } \\
\text { Nickel (Ni), Cadmium (Cd), Total Chrome (Cr) }\end{array}$ \\
\hline
\end{tabular}

According to the uses and the observed values, each parameter was qualitatively classified in terms of: good quality, satisfactory quality, dubious quality, poor quality, and very bad quality. This classification was carried out according to the SEQ-eau model. Then, for each class, we assigned a code (codification) ranging from 0 to 100 , which was used in the analysis as the quality that estimates the parameter; 80-100 correspond to good quality and 0-20 correspond to a very poor quality of water (Table 2).

Table 2. Water quality index classes and codes.

\begin{tabular}{ccc}
\hline Aptitude Class & Color & Description \\
\hline $\mathbf{8 0 ( 8 0 - 1 0 0 )}$ & Blue & Good quality \\
$\mathbf{6 0}(60-80)$ & Green & Satisfactory quality \\
$\mathbf{4 0 ( 4 0 - 6 0 )}$ & Yellow & Dubious quality \\
$\mathbf{2 0 ( 2 0 - 4 0 )}$ & Orange & Bad quality \\
$0(0-20)$ & Red & Very bad quality \\
\hline
\end{tabular}

\subsubsection{Evaluation Method: Weighted Factor Aggregation}

The assessment of the different Water Quality Indices (WQI) of the Ébrié Lagoon consisted of the aggregation or combination of weighted factors (parameters). Thus, these indices were calculated using the following formula:

$$
\mathrm{WQI}=\frac{\sum q_{i} w_{i}}{\sum w_{i}}
$$

where, $q_{i}$ is the quality that estimates the $\mathrm{n}^{\text {th }}$ parameter; $W_{i}$ is the weight of the $\mathrm{n}^{\text {th }}$ parameter.

In this study, the method used to determine the weights of the parameters is the Analytic Hierarchy Process (AHP) created by Saaty [37]. The weighting of the decision criteria was performed using pairwise comparisons method in the context of the Analytic Hierarchy Process (AHP). The method involves pairwise comparisons to create a ratio matrix. It takes as an input the pairwise comparisons and produces the relative weights as output. Specifically, the weights are determined by normalizing the eigenvector associated with the maximum eigenvalue of the (reciprocal) ratio matrix. The development of the pairwise comparison matrix employs an underlying scale with values from 1 to 9 to rate the relative preferences for two criteria (Table 3). The AHP reduce the subjectivity of the weighting process $[38,39]$. 
Table 3. Scale for pairwise comparison of Saaty.

\begin{tabular}{cc}
\hline Intensity of Importance & Definition \\
\hline 1 & Equal importance \\
3 & Moderate importance \\
5 & Strong importance \\
7 & Very strong importance \\
9 & Extreme importance \\
$2,4,6,8$ & Intermediate values between two judgments, used to refine the judgment \\
\hline
\end{tabular}

\section{Results}

\subsection{Weighting of Parameters Per Usage}

Through the AHP method, the parameters' weights of the different uses were determined to allow the evaluation of the Water Quality Indices. Table 4 summarizes the different weights obtained for the WQIs of aquaculture, sports and recreation, irrigation, and livestock watering. For each use, the sum of the weights for each index is equal to 1 .

Table 4. Parameter weights for different uses.

\begin{tabular}{|c|c|c|c|c|c|c|c|}
\hline \multicolumn{2}{|c|}{ Aquaculture } & \multicolumn{2}{|c|}{ Sport and Recreation } & \multicolumn{2}{|c|}{ Irrigation } & \multicolumn{2}{|c|}{ Livestock Watering } \\
\hline Parameter & Weight & Parameter & Weight & Parameter & Weight & Parameter & Weight \\
\hline $\mathrm{Cd}$ & 0.16 & TSS & 0.33 & As & 0.135 & As & 0.16 \\
\hline $\mathbf{P b}$ & 0.13 & Secchi & 0.23 & $\mathbf{P b}$ & 0.2 & $\mathbf{P b}$ & 0.2 \\
\hline Zn & 0.15 & C.Total & 0.19 & $\mathrm{Cd}$ & 0.2 & $\mathrm{Cd}$ & 0.17 \\
\hline $\mathrm{O}$ & 0.08 & C.Thermo & 0.11 & $\mathrm{Zn}$ & 0.21 & $\mathrm{Zn}$ & 0.2 \\
\hline $\mathbf{P}$ & 0.05 & Enterococci & 0.14 & $\mathrm{Cr}$ & 0.18 & $\mathbf{N}$ & 0.04 \\
\hline pH & 0.035 & Sum & 1 & C.Total & 0.041 & $\mathrm{NO}_{2}(-)$ & 0.08 \\
\hline $\mathrm{Cr}$ & 0.13 & & & C.Thermo & 0.034 & $\mathrm{Cr}$ & 0.15 \\
\hline TSS & 0.03 & & & Sum & 1 & Sum & 1 \\
\hline $\mathbf{N}$ & 0.07 & & & & & & \\
\hline $\mathrm{NO}_{2}(-)$ & 0.08 & & & & & & \\
\hline $\mathrm{NH}_{4}(+)$ & 0.085 & & & & & & \\
\hline Sum & 1 & & & & & & \\
\hline
\end{tabular}

\subsection{Spatio-Temporal Analysis of WQIs}

The WQI for aquaculture (Figure 3a) shows the water quality of the lagoon for the month of June 2014. There is bad to very bad water quality in the bays located in the north of the Ébrié Lagoon except at the Bay of Yopougon where the quality is dubious. The southern bays have bad quality water for aquaculture except Koumassi 1 where the quality is dubious. During the same month (June) in 2015, the waters of the bays of Ébrié lagoon are generally of bad to very bad quality (Figure 3b). In December 2014, the quality of the waters of the bays located in the north of the lagoon is generally worse than those of the south (Figure 3c). This trend is statistically conserved in the same month of 2015 (Figure 3d).

During the month of June 2014, we observed that the quality of the Ébrié lagoon waters was dubious to bad for sport and recreation (Figure 4a). Only the Bay of Anna had satisfactory water quality. In 2015, during the month of June, the quality of the waters of the lagoon deteriorated further (Figure 4b). In particular, water in the bay of Cocody went from bad to very bad. The December 2014 results (Figure 4c) show that the water quality varies from dubious to very bad (1 and 2 for Biétri Bay and 3 for Koumassi Bay). The spatial variation in water quality in December 2015 (Figure 4d) is identical to the variation in December 2014: the changes are at the Bays of Koumassi 1 and Canal Est, where the quality went from dubious in 2014 to bad quality in 2015. 


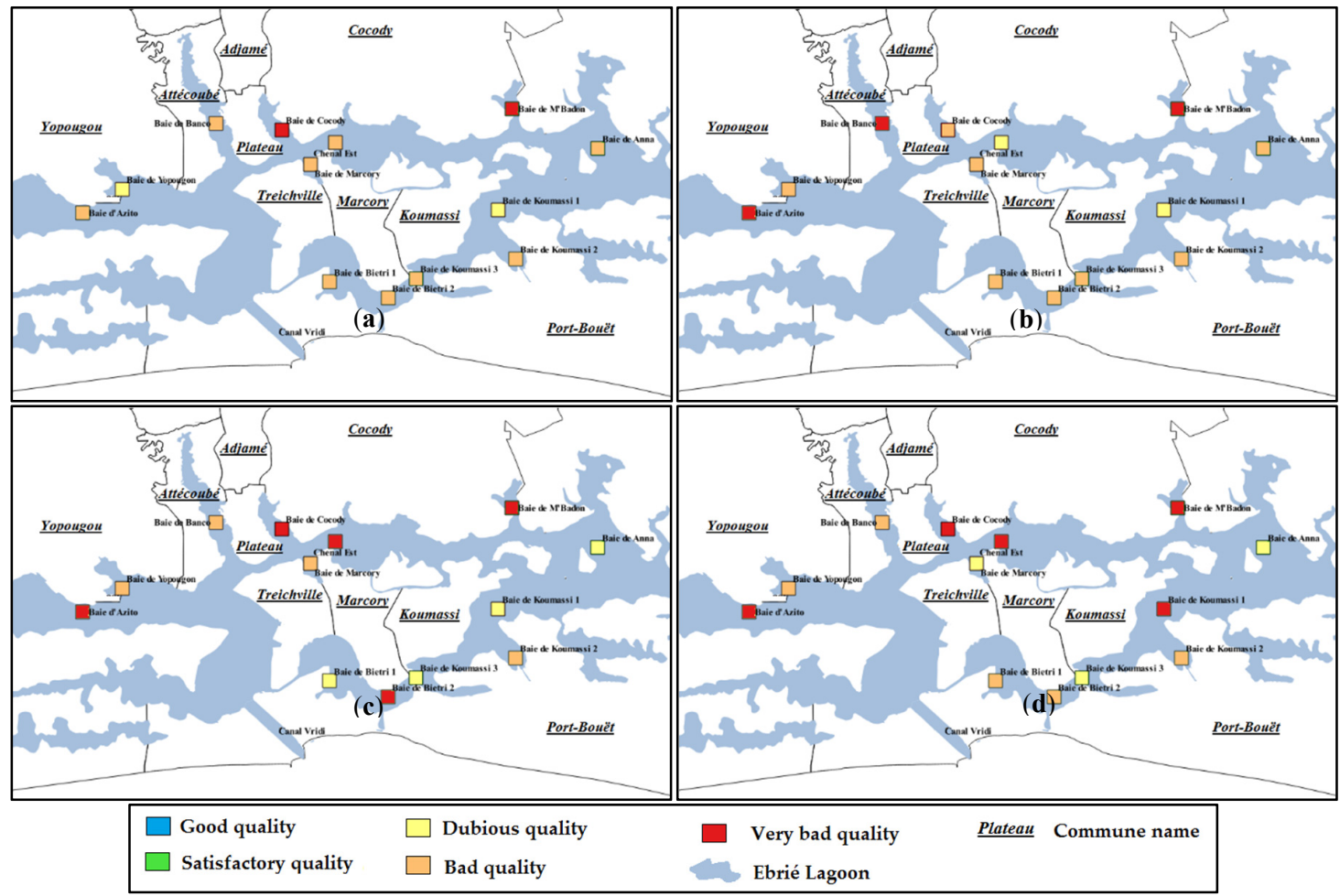

Figure 3. Spatio-temporal variation of the Water Quality Index for aquaculture: (a) June 2014, (b) June 2015, (c) December 2014, and (d) December 2015.

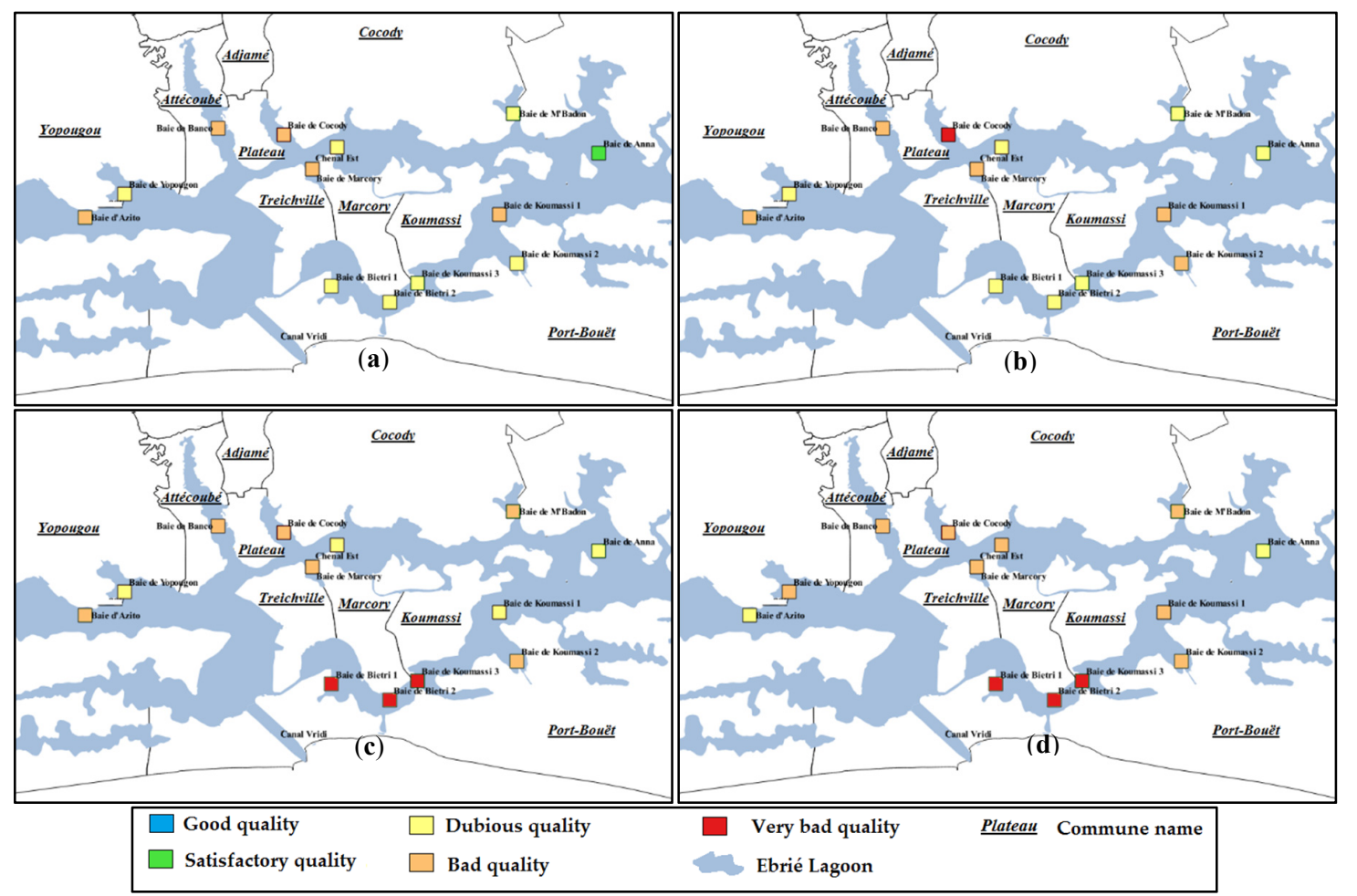

Figure 4. Spatio-temporal variation of the Water Quality Index for sports and recreation: (a) June 2014 (b) June 2015; (c) December 2014; and (d) December 2015. 
Concerning the WQI for irrigation, the obtained results for the month of June 2014 indicate that the lagoon water quality was of bad quality for the purpose of irrigation (Figure 5a) except for the bays of Yopougon and Koumassi 1 where the waters were of dubious quality and at Azito where the quality is very bad. In June 2015 (Figure $5 b$ ), the lagoon water quality varied between bad to very bad quality (the latter being observed at Azito). During the months of December, the lagoon water quality was overall bad or very bad in both 2014 (Figure 5c) and 2015 (Figure 5d). However, we noticed that the degree of pollution was greater in 2015 than it was in 2014. In fact, the bays of Cocody and Koumassi 2, which were of bad quality in 2014, deteriorated to very bad quality in 2015.

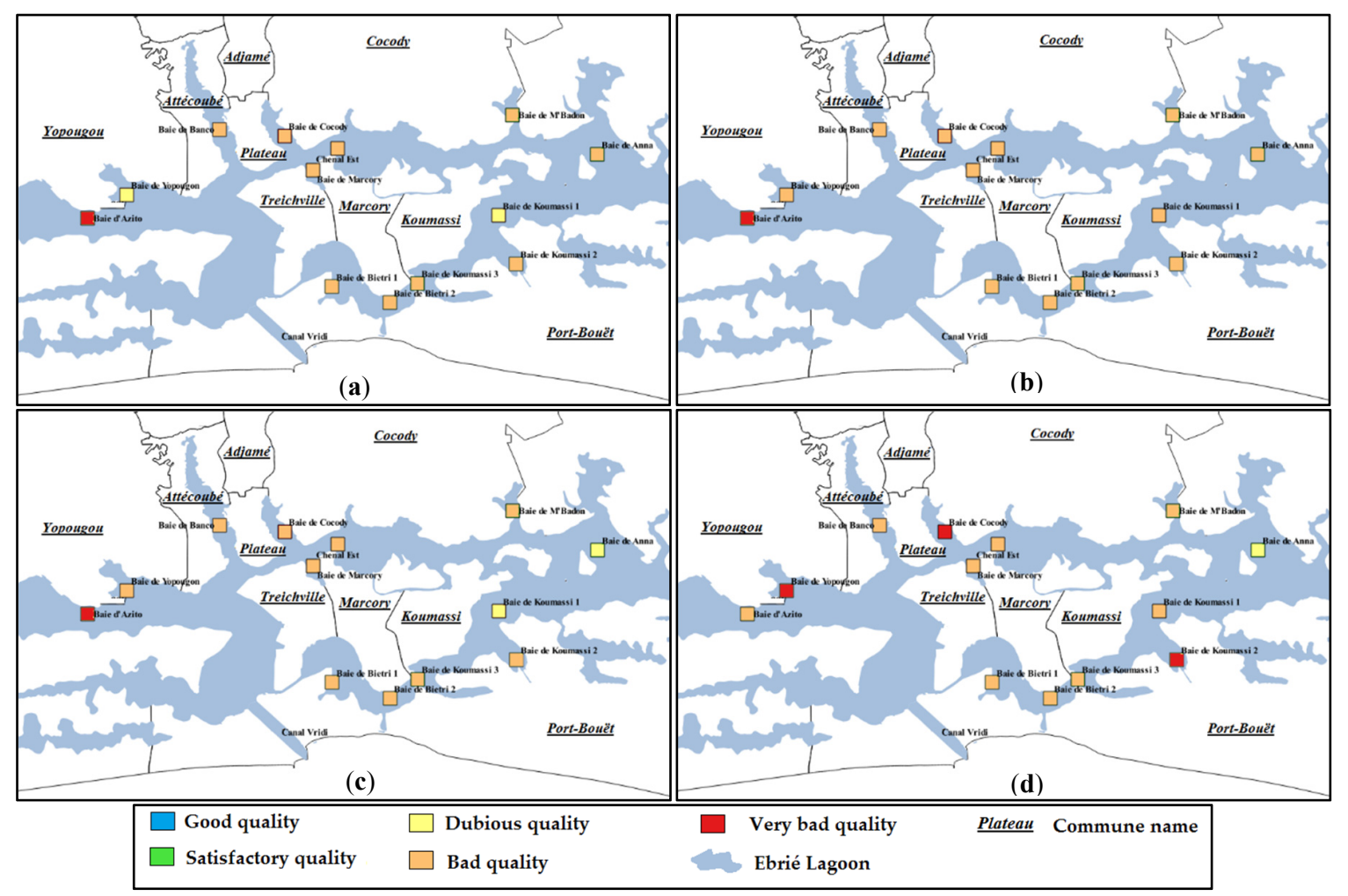

Figure 5. Spatio-temporal variation of the Water Quality Index for irrigation: (a) June 2014; (b) June 2015; (c) December 2014; and (d) December 2015.

The WQI for livestock watering (Figure 6a) shows that the lagoon's water quality varies from dubious to very bad quality for watering in June 2014. The quality is generally bad to very bad in June 2015 (Figure 6b). The water quality in the Bay of Anna remained dubious for watering from June 2014 to June 2015. In December 2014 (Figure 6c), the water quality for livestock watering at all observation points varied from satisfactory quality (at Anna) to very bad quality at Cocody and Azito. In December 2015 (Figure 6d), the waters of the lagoon bays varied from dubious quality (Bays of Banco, Koumassi 1 and Canal East) to very bad quality (Bays of Yopougon and Cocody). 


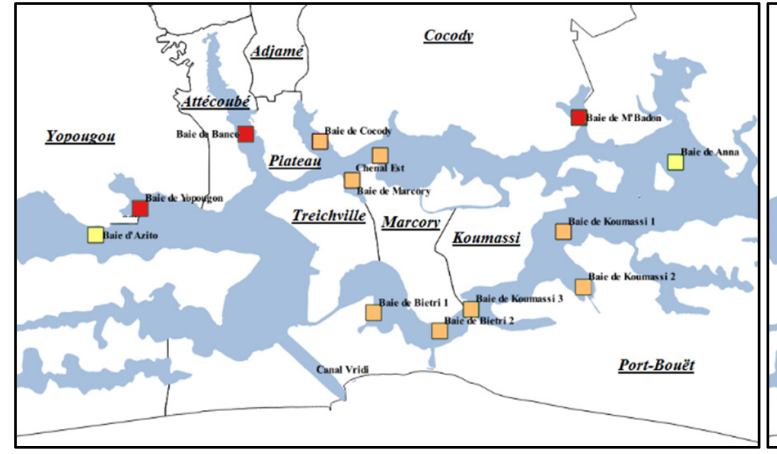

(a)

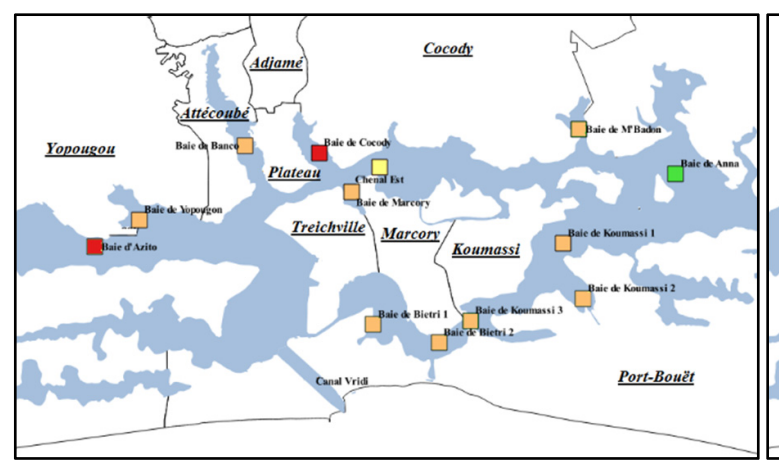

(c)

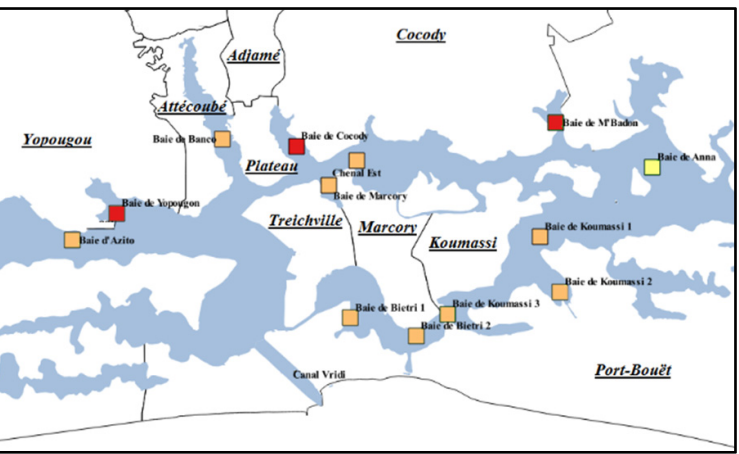

(b)

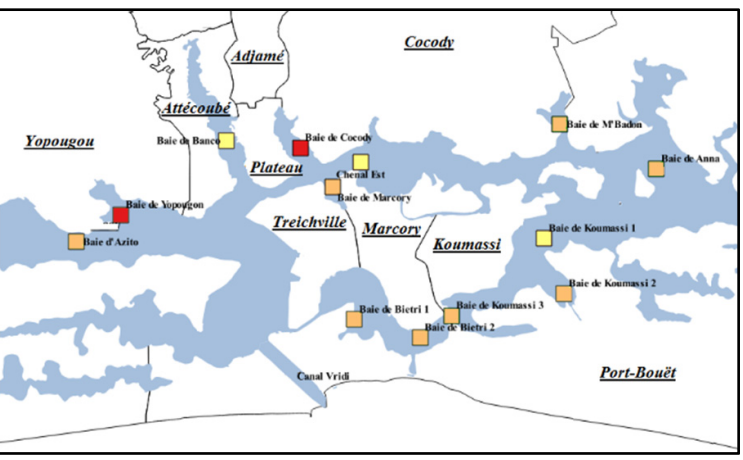

(d)

\begin{tabular}{|llll|}
\hline$\square$ Good quality & $\square$ Dubious quality & Very bad quality & Plateau \\
$\square$ Satisfactory quality & $\square$ Bad quality & Ebrié Lagoon & \\
\hline
\end{tabular}

Figure 6. Spatio-temporal variation of the Water Quality Index for livestock watering: (a) June 2014, (b) June 2015, (c) December 2014, and (d) December 2015.

\section{Discussion}

This work assesses the water quality of the Ébrié lagoon for the following uses: aquaculture, irrigation, livestock watering, and sports and recreation, unlike the previous studies which assessed the level of the general quality with regard to physico-chemical, biological, or heavy metals pollutions [4-19]. The results confirm all previous studies on the Ébrié lagoon (based on a single-parameter method), revealing a well-advanced pollution of lagoon water, especially in the bays where the water renewal rate is very low. The high values of WQIs obtained (for all uses) derive values of each used parameter individually. Regarding the concentration of heavy metals of the used data, they highlight a high level contamination by heavy metals. The mean observed values in terms of contents in sediment in $\mathrm{mg} / \mathrm{kg}$ are 245.73, 138.34, 59.33, 19.25, and 7.85 for $\mathrm{Zn}, \mathrm{Cr}, \mathrm{Pb}$, As, and Cd respectively. The values of Total Coliform, Thermotolerant Coliform, and Enterrococci vary respectively from 1500 (Anna Bay) to 2,500,000 (Cocody and Marcory Bays) in number $/ 100 \mathrm{~mL}$ and from de 60 (Anna Bay) to 75,000 (Biétry 1 Bay) in number/100 mL, evidence of a high faecal contamination except at Anna Bay. The control bacteria density of this type of contamination observed in 1992 by Guiral and Kouassi [40] were already indicating a high faecal pollution of the banks of the lagoon and particularly bays (confined areas). Also, compared to the World Health Organization (WHO) standards, Adingra et al. [12] had concluded in their works that the waters of the lagoon at Abidjan are unsuitable for sports, tourism, and cultural activities. According to these authors, today, social capital resulting from these activities no longer exists and children who continue to swim in the lagoon are exposed to high levels of risk of diarrheal diseases and all other diseases which can be caused by these waters. Indeed, traditionally, the lagoon is the bathing place of the children of the riparian population. 
Furthermore, we note that the bay of Anna, located on the Eastern outskirts of Abidjan (Figure 1) is relatively less polluted. At this bay, it is noted that the drainage basin that drains this bay is the least urbanized with a land use rate less than $30 \%$. That could confirm the finding that the quality of the lagoon water is notably affected by anthropogenic activities such as agriculture, industry, and urban growth.

The spatio-temporal analysis of the WQIs for the fourth uses shows a slight deterioration of the water of the lagoon from 2014 to 2015 in general. These observations are in line with those of Wu et al. [41], who have obtained a deteriorating trend at the inter-annual scale using WQIs in Lake Poyang, the largest freshwater lake in China. This situation is explained by the permanent flows of pollutants (domestic and industrial, or agricultural) that arrive in these bays. Exceptionally, there is an improvement in the quality of the water in certain bays. This may be due to the hydrological regime of the Ébrié Lagoon. In fact, river flows from Comoé, Mé and Agnéby contribute towards diluting the waters of the lagoon, thus reducing pollution according to Durand and Guiral [42], even if this phenomenon is not important in the bays which are perpendicular ramifications to the main axis of the lagoon.

The results obtained in this work depend, on the one hand, on the chosen parameters and their classification according to their different concentrations, and on the second hand, on the weighting of the parameters or their perceived importance to the overall quality of water. In any event, the WQIs of this study are open to allow the flexibility of inclusion or exclusion of any parameter as the WQIs developed by Sharma and Reddy [43]. The WQIs obtained will be an immense help in deciding the strategies and programs for the lagoon water quality management.

\section{Conclusions}

This study involved a spatio-temporal analysis of the water quality of the Ébrié lagoon at the city of Abidjan, the economic capital of Côte d'Ivoire. The selected parameters used in this analysis were those defined by SEQ-eau for the uses of: irrigation, sport and recreation, aquaculture, and livestock watering. The method consisted of calculating Water Quality Indices (WQIs) for the different selected uses using a weighted factor aggregation approach. The results of the assessment of the water quality of the Ébrié lagoon for June and December of 2014 and 2015 have shown that the quality of the water of the studied bays varies from dubious to very bad quality for all uses: aquaculture, irrigation, recreation and sports, and livestock watering.

In perspectives, the values of the WQIs obtained in this study can be improved by taking into account the specificity of the city of Abidjan and the Ébrié lagoon water body, and a statistical approach could be used to identify relevant parameters. Also, it would be judicious to study the seasonally real impact of the Comoé River flows on the lagoon water quality to assess the impact of opening of the River's mouth located at Grand-Bassam on the lagoon water's quality because this action would deprive the lagoon of a significant part of flows crucial for the renewal of its waters.

Author Contributions: C.N. developed the idea and evaluated the WQIs, A.H.S. prepared data. C.N., C.T.J.H., O.A.D. and Y.O.B. contributed to the analyses, interpretation of results and wrote the paper. Z.S.G. and Z.M. and S.I. revised the paper.

Funding: This research received no external funding.

Acknowledgments: The authors thank the Centre Ivoirien d'Anti-Pollution (CIAPOL) of the Ministère de la Salubrité, de l'Environnement et du Développement Durable (MINSEDD) who produced data for this work and the SGIE for the framework of collaboration around environmental information of Côte d'Ivoire the coastal zone.

Conflicts of Interest: The authors declare no conflicts of interest. 


\section{References}

1. Pottier, P.; Affian, K.; Djagoua, M.V.; Anoh, K.P.; Kra, Y.; Kangah, A.; Robin, M. La lagune Ebrié à l'épreuve de la pression anthropique. In Géographie du Littoral de la Côte d'Ivoire: Éléments de Réflexion Pour une Politique de Gestion Intégrée; Pottier, P., Anoh, K.P., Eds.; Coopération Universitaire Cocody: Abidjan, Côte d'Ivoire; Nantes, France, 2008; pp. 165-184.

2. Dufour, P.; Kouassi, A.M.; Lanusse, A. Les pollutions. In Environnement et Ressources Aquatiques de Côte d'Ivoire. Tome 2: Les Milieux Lagunaires; Durand, J.-R., Dufour, P., Guiral, D., Zabi, S.G.F., Eds.; Orstom: Abidjan, Côte d'Ivoire, 1994; pp. 309-333.

3. Zabi, S.G.F. Les peuplements benthiques liés à la pollution en zone urbaine d'Abidjan (Côte d'Ivoire). Oceanol. Acta 1982, 4, 441-455.

4. Marchand, M.; Martin, J.L. Détermination de la pollution chimique (hydrocarbures, organochlorés, métaux) dans la lagune d'Abidjan (Côte d'Ivoire) par l'étude des sédiments. Océanogr. Trop. 1985, 20, $26-39$.

5. Métongo, B.; Kouassi, A.; Kaba, N.; Centre de Recherche Océanologiques, Abidjan, Côte d'Ivoire. Personal communication, 1993.

6. Kouassi, A.M.; Kaba, N.; Métongo, B.S. Land-based sources of pollution and environnemental quality of the Ebrié lagoon waters. Mar. Pollut. Bull. 1995, 30, 295-300. [CrossRef]

7. Adingra, A.A.; Arfi, R. Organic and bacterial pollution in the Ebrié lagoon, Côte d'Ivoire. Mar. Pollut. Bull. 1998, 36, 689-695. [CrossRef]

8. Scheren, P.A.G.M.; Kroeze, C.; Janssen, F.J.J.G.; Hordijk, L.; Ptasinski, K.J. Integrated water pollution assessment of the Ebrié Lagoon, Ivory Coast, West Africa. J. Mar. Syst. 2004, 44, 1-17. [CrossRef]

9. Yao, K.M.; Métongo, B.S.; Trokourey, A.; Bokra, Y. Détermination de certains paramètres de pollution dans les baies d'une lagune tropicale: La lagune Ebrié (Côte d'Ivoire). J. Ivoir. Océanol. Limnol. 2007, 4, 1-10.

10. Coulibaly, A.S.; Monde, S.; Wognin, V.A.; Aka, K. State of antropic pollution in the estuary of Ebrié lagoon (Côte d'Ivoire) by analysis of the metal traces. Eur. J. Sci. Res. 2008, 19, 371-390.

11. Soro, G.; Metongo, S.B.; Soro, N.; Ahoussi, K.E.; Kouamé, K.F.; Zadé, S.G.P.; Soro, T. Métaux lourds (Cu, $\mathrm{Cr}, \mathrm{Mn}$, et $\mathrm{Zn}$ ) dans les sédiments de surface d'une lagune tropicale africaine. Cas de la lagune Ebrié (Côte d'Ivoire). Int. J. Biol. Chem. Sci. 2009, 3, 1408-1427. [CrossRef]

12. Adingra, A.A.; Kouassi, A.M.F. Pollution en lagune Ebrié et ses impacts sur l'environnement et les populations riveraines. Fiches Tech. Doc. Vulg. 2011, 2011, 48-53.

13. Coulibaly, T.J.H.; Coulibaly, N.; Koffi, D.; Camara, M.; Savane, I. Cartographie des zones à l'origine de l'ensablement des canaux du bassin versant du Gourou (Abidjan-Côte d'Ivoire). IJIAS 2014, 6, 642-653.

14. Inza, B.; Yao, K.M. Paramètres physiques et chimiques et métaux lourds des eaux de la Lagune Ebrié (Côte d'Ivoire): Influence de la marée et des effluents liquides urbaines. J. Mater. Environ. Sci. 2015, 6, 1321-1329.

15. Akpo, S.K.; Ouattara, P.J.M.; Eba, M.G.; Ouffouet, S.; Coulibaly, L. Etat de la pollution fécale dans les baies de la lagune Ebrié (Banco, Cocody et M’Badon) à Abidjan, Côte d'Ivoire. J. Mater. Environ. Sci. 2016, 7, 621-630.

16. Kouamé, K.D.; Yapo, O.B.; Miété, L. Contamination des sédiments d'une lagune tropicale urbaine par les éléments traces métalliques (As, $\mathrm{Cd}, \mathrm{Cr}, \mathrm{Pb}, \mathrm{Zn}$ ): CAS des baies lagunaires de la ville d'Abidjan (Côte d'Ivoire). Int. J. Pure Appl. Biosci. 2016, 4, 204-217.

17. Tia, L. Gestion Des Matières Résiduelles Et Pollution Lagunaire A Abidjan: Responsabilités, Stratégies et Perspectives. Eur. Sci. J. 2017, 13, 1857-1881. [CrossRef]

18. Koné, M.; Aka, K. Les lagunes d'Abidjan asphyxiées par la pollution. Afr. Geosci. Rev. 1995, 3, 461-470.

19. Kouamé, K.D.; Yapo, O.B.; Méité, L. Heavy metal concentrations in some benthic organisms (callinectes amnicola) from Ebrié lagoon, Abidjan Côte d'Ivoire. Asian J. Sci. Technol. 2017, 8, 6681-6685.

20. Bordalo, A.A.; Teixeira, R.; Wiebe, W.J. A water quality index applied to an international sharedriver basin: The case of the Douro River. Environ. Manag. 2006, 38, 910-920. [CrossRef] [PubMed]

21. Horton, R.K. An index number system for rating water quality. J. Water Pollut. Control Fed. 1965, 37, 300-306.

22. Lumb, A.; Halliwell, D.; Sharma, T. Canadian Water Quality Index to Monitor the Changes in Water Quality in the Mackenzie River-Great Bear. In Proceedings of the 29th Annual Aquatic Toxicity Workshop, Whistler, BC, Canada, 21-23 October 2002.

23. Debels, P.; Figueroa, R.; Urrutia, R.; Barra, R.; Niell, X. Evaluation of water quality in the Chillan River (Central Chile) using physicochemical parameters and a modified water quality index. Environ. Monit. Assess. 2005, 110, 301-322. [CrossRef] [PubMed] 
24. Akoteyon, I.S.; Omotayo, A.O.; Soladoye, O.; Olaoye, H.O. Determination of water quality index and suitability of urban river for municipal water supply in Lagos, Nigeria. Eur. J. Sci. Res. 2011, 54, $263-271$.

25. Semiromi, F.B.; Hassani, A.H.; Torabian, A.; Karbassi, A.R.; Lotfi, F.H. Water quality index development using fuzzy logic: A case study of the Karoon River of Iran. Afr. J. Biotechnol. 2011, 10, 10125-10133.

26. Abbasi, T.; Abbasi, S. Water Quality Indices, 1st ed.; Elsevier: Amsterdam, The Netherlands, 2012.

27. Wanda, E.M.; Gulula, L.C.; Phiri, G. Determination of characteristics and drinking water quality index in Mzuzu City, Northern Malawi. Phys. Chem. Earth Parts A/B/C 2012. [CrossRef]

28. Tyagi, S.; Sharma, B.; Singh, P.; Dobhal, R. Water quality assessment in terms of water quality index. Am. J. Water Resour. 2013, 1, 34-38.

29. Bhutiani, R.; Khanna, D.R.; Kulkarni, D.B.; Ruhela, M. Assessment of Ganga river ecosystem at Haridwar, Uttarakhand, India with reference to water quality indices. Appl. Water Sci. 2014. [CrossRef]

30. Akter, T.; Jhohura, F.T.; Akter, F.; Chowdhury, T.R.; Mistry, S.K.; Dey, D.; Barua, M.K.; Islam, M.A.; Rahman, M. Water Quality Index for measuring drinking water quality in rural Bangladesh: A cross-sectional study. J. Health Popul. Nutr. 2016, 35. [CrossRef] [PubMed]

31. Imneisi, I.B.; Aydin, M. Water Quality Index (WQI) for Main Source of Drinking Water (Karaçomak Dam) in Kastamonu City, Turkey. J. Environ. Anal. Toxicol. 2016, 6. [CrossRef]

32. Bora, M.; Goswami, D.C. Water quality assessment in terms of water quality index (WQI): Case study of the Kolong River, Assam, India. Appl. Water. Sci. 2017, 7, 3125-3135. [CrossRef]

33. Şener, Ş.; Şener, E.; Davraz, A. Evaluation of water quality using water quality index (WQI) method and GIS in Aksu River (SW-Turkey). Sci. Total Environ. 2017, 15, 131-144. [CrossRef] [PubMed]

34. Tastet, J.-P.; Guiral, D. Géologie et sédimentologie. In Environnement et Ressources Aquatiques de Côte d'Ivoire. Tome 2: Les Milieux Lagunaires; Durand, J.-R., Dufour, P., Guiral, D., Zabi, S.G.F., Eds.; Orstom: Abidjan, Côte d'Ivoire, 1994; pp. 59-90.

35. Affian, K. Approche Environnementale d'un Écosystème Lagunaire Microtidal (la Lagune Ébrié en Côte d'Ivoire), par des Études Géochimiques, Bathymétriques et Hydrologiques: Contribution du SIG et de la Télédétection. Ph.D. Thesis, Université de Cocody, Abidjan, Côte d'Ivoire, 2003.

36. SEQ-EAU, Système D'évaluation de la Qualité de l'Eau des Cours D'eau. Rapport D'étude des Agences de l'Eau. 2003. Available online: http:/ / rhin-meuse.eaufrance.fr/IMG/pdf/grilles-seq-eau-v2.pdf (accessed on 24 April 2018).

37. Saaty, T.L. The Analytic Hierarchy Process: Planning, Priority Setting, Resource Allocation; McGraw-Hill International Book Co.: New York, NY, USA, 1980.

38. Hanadi, I.; Zaher, Z.; Samer, F.; Hussein, A.-H. Comparative Analysis of Results Obtained from 3 Indexes (SEQ-Eau, IBD, IPS) Used to Assess Water Quality of the Berdawni, A Mediterranean Stream at the Beqaa Region-Lebanon. IJSTR 2015, 4, 34-40.

39. Hanadi, I.; Hussein, A.-H.; Yolla, B.; Ahmad, C. Comparative Analysis of Two Indices (SEQ-Eau and IBMR) to Assess Water Quality of the Ghouzaiel, A Mediterranean Streamat Beqaa Region—Lebanon. IJASTR 2016, $6,357-366$.

40. Guiral, D.; Kouassi, A.M. Estimation à proximité des berges des niveaux de pollutions organique et bactérienne des eaux lagunaires de la ville d'Abidjan (lagune Ébrié, Côte-d'lvoire). J. Ivoir. Oceanol. Limnol. 1992, 2, 18-41.

41. Wu, Z.; Zhang, D.; Cai, Y.; Wang, X.; Zhang, L.; Chen, Y. Water quality assessment based on the water quality index method in Lake Poyang: The largest freshwater lake in China. Sci. Rep. 2017, 7. [CrossRef] [PubMed]

42. Durand, J.R.; Guiral, D. Hydroclimat et hydrochimie. In Environnement et Ressources Aquatiques de Côte d'Ivoire. Les Milieux Lagunaires; Durand, J.-R., Dufour, P., Guiral, D., Zabi, S.G.F., Eds.; Orstom: Abidjan, Côte d'Ivoire, 1994; pp. 59-90.

43. Sharma, S.; Reddy, A.S. Development of Water Quality Indices for Designated Best Uses of Surface Water Body. Int. J. Eng. Sci. Innov. Technol. 2013, 2, 82-93.

(C) 2018 by the authors. Licensee MDPI, Basel, Switzerland. This article is an open access article distributed under the terms and conditions of the Creative Commons Attribution (CC BY) license (http:/ / creativecommons.org/licenses/by/4.0/). 